\title{
SOME EFFEGTS OF SMELTER POLLUTION UPON AQUATIC VEGETATION NEAR SUDBURY, ONTARIO
}

\author{
Eville Gorham \\ Botany Department, University of Toronto, Toronto, Ontario \\ AND \\ Alan G. Gordon \\ Research Brancl, Ontario Department of Lands and Forests, Forest Biology Laboratory, \\ Sault Ste Marie, Ontario \\ Received December 6, 1962
}

\begin{abstract}
The numbers of submerged and floating macrophyte species present in 29 ponds and lakes are inversely related to dissolved sulphates, concentrations of which rise sharply within about 4 to 5 miles of the smelters. Although pollution of ten leads to strong acidification, numbers of species are low even where sulphuric acid is almost wholly neutralized, and waters are above $\mathrm{pH} 6$. Because sulphate ions are unlikely to be toxic at the levels encountered, and since pollution also increases the concentration of heavy metals in the waters, it is suggested that these may reach toxic levels near the smelters.

Leptodictyum riparium and Eleocharis acicularis v. submersa seem to be most tolerant of smelter pollution, while Utricularia inlgaris and Potamogeton epihydrus v. nuttallii appear rather sensitive to it.
\end{abstract}

\section{Introduction}

In the course of studies upon smelter pollution and its ecological significance near Sudbury, Ontario (Gorham and Gordon 1960a, 1960b), a sharp rise in sulphate concentration of lake and pond waters was observed within about 4 to 5 miles of the smelter chimneys, owing to oxidation and fallout of sulphur dioxide emitted during the smelting process. In order to examine the effect of smelter pollution upon aquatic vegetation, a floristic survey of 29 lakes and ponds was undertaken.

\section{Methods}

During the summer of 1959, 102 lakes and ponds were visited by car or helicopter, and water samples were collected for analysis of $\mathrm{pH}$, calcium, and sulphate (Gorham and Gordon 1960b). In a representative selection of 14 waters the aquatic vegetation was surveyed, between September 5 and 9 , by collecting and pressing material of every species of floating or submerged macrophyte (including bryophytes and Characeae) observed in 20 minutes swimning by two men equipped with fins, face masks, and schnorkel breathing tubes. Between August 16 and 19, 1960, a further 15 waters were examined, including 3 not visited in 1959. Species with energent leaves were not included, unless growing wholly submerged, as was frequently the case with Lysimachia terrestris, and once with Juncus militaris, which has very characteristic submerged leaves.

The locations of the lakes and ponds are given in Table I.

Canadian Journal of Botany. Volume 41 (1963) 
TABLE I

Numbers of aquatic macrophytes and chemical composition of Sudbury waters

\begin{tabular}{|c|c|c|c|c|c|c|c|c|}
\hline $\begin{array}{l}\text { Lake } \\
\text { No. }\end{array}$ & $\begin{array}{l}\text { Miles to } \\
\text { smelter }\end{array}$ & $\begin{array}{l}\text { Direction } \\
\text { from smelter }\end{array}$ & Smelter* & $\begin{array}{l}\mathrm{SO}_{4} \\
\mathrm{meq} / 1 .\end{array}$ & $\begin{array}{c}\mathrm{Ca}, \\
\mathrm{meq} / \mathrm{l}\end{array}$ & $\begin{array}{c}\mathrm{pH} \\
\text { aerated }\end{array}$ & $\begin{array}{l}\text { Damage to } \\
\text { terrestrial } \\
\text { vegetationt }\end{array}$ & $\begin{array}{l}\text { No. species } \\
\text { aquatic } \\
\text { macrophytes }\end{array}$ \\
\hline 8 & 0.9 & S. & $\mathrm{F}$ & 2.75 & 0.70 & 3.3 & $\mathrm{~S}$ & 1 \\
\hline 12 & 1.2 & N. & $\mathrm{F}$ & 1.48 & 0.55 & 3.6 & $\mathrm{C}$ & 0 \\
\hline 53 & 1.2 & NW. & $\mathrm{CC}$ & 1.56 & 0.58 & 4.1 & VS & 3 \\
\hline 11 & 1.5 & N. & $F$ & 1.36 & 0.39 & 3.5 & $\mathrm{~S}$ & 4 \\
\hline 54 & 1.8 & NW. & $\mathrm{CC}$ & 1.16 & 0.50 & 4.2 & $\overrightarrow{\mathrm{s}}$ & 3 \\
\hline 65 & 1.8 & SSW. & $\mathrm{C}$ & 1.88 & 1.04 & 6.1 & $\mathrm{~S}$ & 2 \\
\hline 14 & 2.3 & N. & $\mathrm{F}$ & 0.58 & 0.21 & 3.9 & $\mathrm{C}$ & 2 \\
\hline 56 & 2.5 & NW. & $\mathrm{CC}$ & 0.77 & 0.49 & 6.3 & $\mathrm{C}$ & 4 \\
\hline 4 & 2.8 & WSW. & $F$ & 1.01 & 0.64 & 4.3 & $\widehat{S}$ & 4 \\
\hline 15 & 3.1 & NNE. & $\mathrm{F}$ & 0.63 & 0.27 & 4.1 & C & 4 \\
\hline 69 & 3.2 & NE. & $\mathrm{C}$ & 1.80 & 0.97 & 6.4 & $\overline{\mathrm{S}}$ & 5 \\
\hline 21 & 3.5 & SSE. & $\mathrm{CC}$ & 1.11 & 0.56 & 4.2 & $\mathrm{C}$ & 8 \\
\hline 17 & 4.0 & NNE. & $F$ & 0.60 & 0.98 & 7.9 & $\mathrm{M}$ & 7 \\
\hline 22 & 4.2 & S. & $\mathrm{CC}$ & 0.71 & 0.34 & 4.3 & $\mathrm{C}$ & 5 \\
\hline 75 & 6.9 & SSE. & $\mathrm{C}$ & 0.49 & 0.27 & 5.6 & $\mathrm{~N}$ & 4 \\
\hline 23 & 7.0 & SSW. & $\mathrm{CC}$ & 0.63 & 0.48 & 7.0 & $\mathrm{~N}$ & 11 \\
\hline 33 & 7.4 & SW. & C & 0.46 & 0.28 & 6.6 & $\mathrm{~N}$ & 8 \\
\hline 24 & 10.6 & SW. & $\mathrm{CC}$ & 0.51 & 0.31 & 6.3 & $\mathrm{~N}$ & 7 \\
\hline 25 & 13.3 & SW & $\mathrm{CC}$ & 0.47 & 0.37 & 7.0 & $\mathrm{~N}$ & 17 \\
\hline 96 & 15.6 & NNE. & $F$ & 0.47 & 0.26 & 5.6 & $\mathrm{~N}$ & 10 \\
\hline 29 & 16.4 & S. & $\mathrm{CC}$ & 0.36 & 0.21 & 4.6 & $\mathrm{~N}$ & 6 \\
\hline 26 & 19.2 & SW. & $\mathrm{CC}$ & 0.24 & 0.27 & 7.2 & $\mathrm{~N}$ & 11 \\
\hline 95 & 19.4 & NNE. & F & 0.37 & 0.17 & 4.4 & $\mathrm{~N}$ & 10 \\
\hline 94 & 19.8 & WNW. & $\mathrm{CC}$ & 0.24 & 0.18 & 6.0 & $\mathrm{~N}$ & 17 \\
\hline 27 & 23.4 & SW. & $\mathrm{CC}$ & 0.29 & 0.34 & 7.4 & $\mathrm{~N}$ & 10 \\
\hline 28 & 24.2 & SW. & $\mathrm{CC}$ & 0.39 & 0.41 & 7.4 & $\mathrm{~N}$ & 24 \\
\hline 103 & 31 & WNW. & $\mathrm{CC}$ & 0.25 & 0.25 & 6.8 & $\mathrm{~N}$ & 18 \\
\hline 105 & 33 & WNW. & $\mathrm{CC}$ & 0.27 & 0.28 & 6.9 & $\mathrm{~N}$ & 1 \\
\hline 104 & 34 & WNW. & $\mathrm{CC}$ & 0.29 & 0.25 & 6.4 & $\mathrm{~N}$ & 18 \\
\hline
\end{tabular}


TABLE II *Might be in $11,22,25,95$, and 96, from which mosses were recorded in 1959 . These moss samples have been mislaid, and might represent either Leptodictyum riparium
or Drepanocladus fluitans.

Submerged and floating macrophytes identified in five or more lakes and ponds

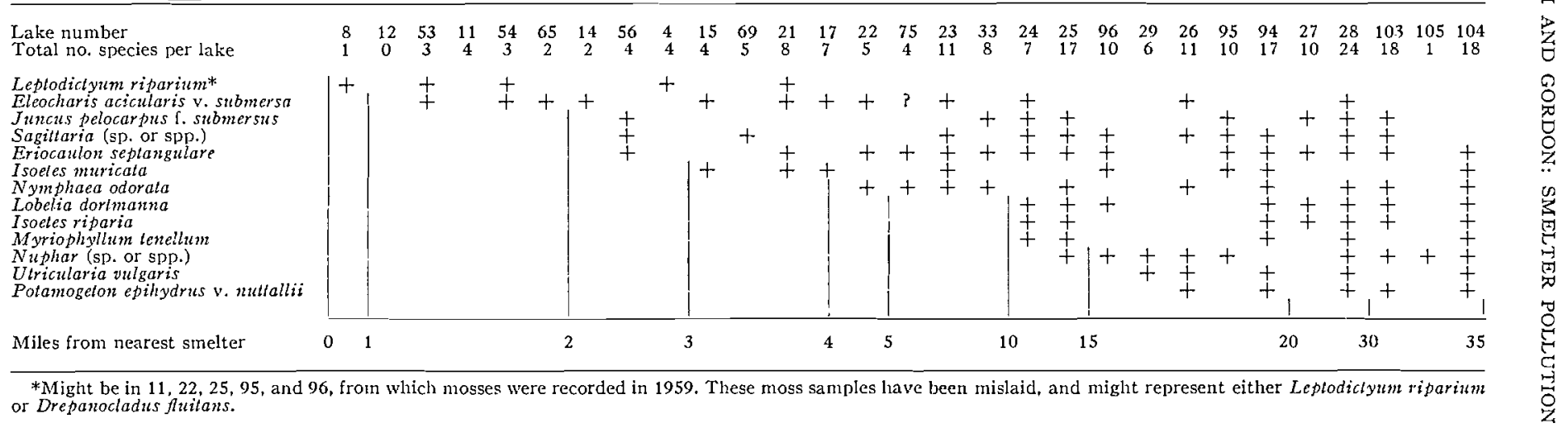


TABLE III

Submerged or floating nacrophytes identified in fewer than five lakes and ponds

\begin{tabular}{|c|c|c|c|}
\hline Higher plants & Lakes & Bryophytes & Lakes \\
\hline $\begin{array}{l}\text { Brasenia schreberi } \\
\text { Elatine minima } \\
\text { Eleocharis robbinsii } \\
\text { Glyceria borealis } \\
\text { Hippuris vulgaris } \\
\text { Juncus militaris } \\
\text { Lysimachia terrestris } \\
\text { Myriophyllum farwelli } \\
\text { Najas fiexilis } \\
\text { Polygonum amphibium } \\
\text { Potamogeton amplifolius } \\
\text { P. gramineus } \\
\text { P. pectinatus } \\
\text { P. pusillus } \\
\text { P. robbinsii } \\
\text { P. spirillus } \\
\text { Sparganium fluctuans } \\
\text { Utricularia gibba } \\
\text { U. intermedia } \\
\text { U. minor } \\
\text { U. purpurea }\end{array}$ & $\begin{array}{l}27,28,104 \\
25 \\
29 \\
69 \\
104 \\
103 \\
23,26,28,103 \\
28,103 \\
28 \\
17,69 \\
28 \\
17,27,28 \\
95,25,104 \\
23,25 \\
27,94,103 \\
28,94,33,104 \\
25,26, \\
23 \\
96,103 \\
95 \\
94,96\end{array}$ & $\begin{array}{l}\text { Cladopodiella fuitans } \\
\text { Drepanocladus fuitans* } \\
\text { Fontinalis novae-angliae } \dagger \\
\text { Polytrichum conmune } \ddagger\end{array}$ & $\begin{array}{l}\begin{array}{l}4,21 \\
23,29,94 \\
26,94,104 \\
54\end{array}\end{array}$ \\
\hline
\end{tabular}

tProbably also in $25,26,25,95$, and 950 , mislaid. 1959 mislaid. 


\section{Results}

Table I also gives the total number of species recorded for each body of water, together with data on water chemistry and a visual estimate of damage to nearby terrestrial vegetation, included from the earlier study.

Within 2 miles of the smelters, the total number of species observed ranged from 0 to 4 ; between 2 and 5 miles this range increased to between 2 and 8 species; while outside 15 miles the range was from 6 to 24 , except for a single lake (No. 105) where only 1 species was recorded. Ranges for dissolved sulphate were 1.16 to $2.75 \mathrm{meq} / 1$. within 2 miles and 0.24 to $0.47 \mathrm{meq} / 1$. outside 15 miles. For $\mathrm{pH}$, these same ranges were 3.3 to 6.1 and 4.4 to 7.4 ; and for calcium 0.4 to $1.0 \mathrm{meq} / 1$. and 0.2 to $0.4 \mathrm{meq} / \mathrm{l}$. Where Table I records damage to terrestrial vegetation, the maximum number of species recorded was 8 , as against 24 where such damage was not obvious.

Table II shows the distribution of all the species identified in five or more sites, and thus gives an idea of the aquatic flora typical of this area. (Some species may have occurred elsewhere as well, but not in identifiable form or in the area traversed by swimming; and the records for Nuphar and Sagittaria may refer to more than one species, since flowers and fruits were seldom available.) Both Eleocharis acicularis v. submersa and Juncus pelocarpus $\mathrm{f}$. submersus were difficult to identify conclusively from keys, but finally compared well with material of the submerged forms of these species in the herbarium at Toronto. Table III rounds out the floristic picture by giving species identified in fewer than five waters. Characeae were not identified to species.

Sonne species appeared relatively tolerant of pollution; for example Leptodictyum riparium (a moss) and Eleocharis acicularis v. submersa were found within 2 miles of the smelters. Leptodictyum sp. has been recorded by Yoshimura (1935) as usually covering the bottom of inorganic acid lakes in Japan, where volcanic waters rich in sulphuric acid are common. Polytrichum has also been recorded as a natural inhabitant of an acid Japanese lake, bearing out the apparent naturalization of Polytrichum commune in one of the Sudbury lakes (No. 54, $\mathrm{pH} 4.2, \mathrm{SO}_{4} 1.16 \mathrm{meq} / 1$.). It should also be noted that wefts of algae covered much of the littoral zone in several of the most highly polluted waters, which were thus by no means devoid of vegetation. On the other hand, Utricularia vulgaris and Potamogeton epihydrus v. nuttallii were only observed beyond 15 miles from the smelters, where, however, they occurred in 5 of the 10 waters investigated.

\section{Discussion}

It is apparent from Table I that smelter pollution drastically reduces the aquatic flora in the immediate vicinity of Sudbury. And while the present study was concerned with only floristic diversity, it was also evident that heavy pollution greatly reduces productivity, so that in lakes with few species the standing crops of macrophytes are commonly very low. The area subject to severe pollution lies within about 4 to 5 miles of the three smelters, as shown in Fig. 1, where sulphate concentration $(x)$ is plotted versus distance from the nearest smelter $(z)$. The regression is adequately expressed by the equation $x=1.73 z^{-0.555}$, with the standard error of estimate \pm 0.13 nieq/l., and the correlation coefficient $r=-0.92$, although the $\log / \log$ plot inset in Fig. 1 shows a slight tendency to be curvilinear. 


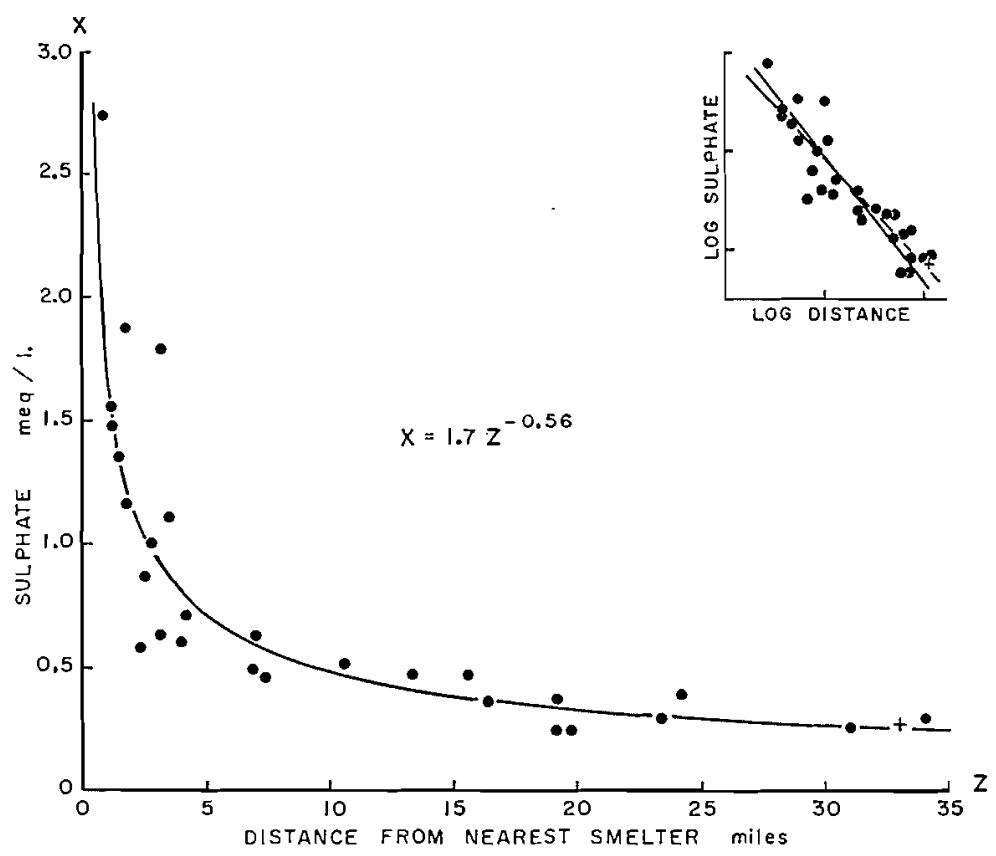

FIG. 1. The relation between sulphate concentration in pond and lake waters and distance from smelters (point + represents lake No. 105, see text).

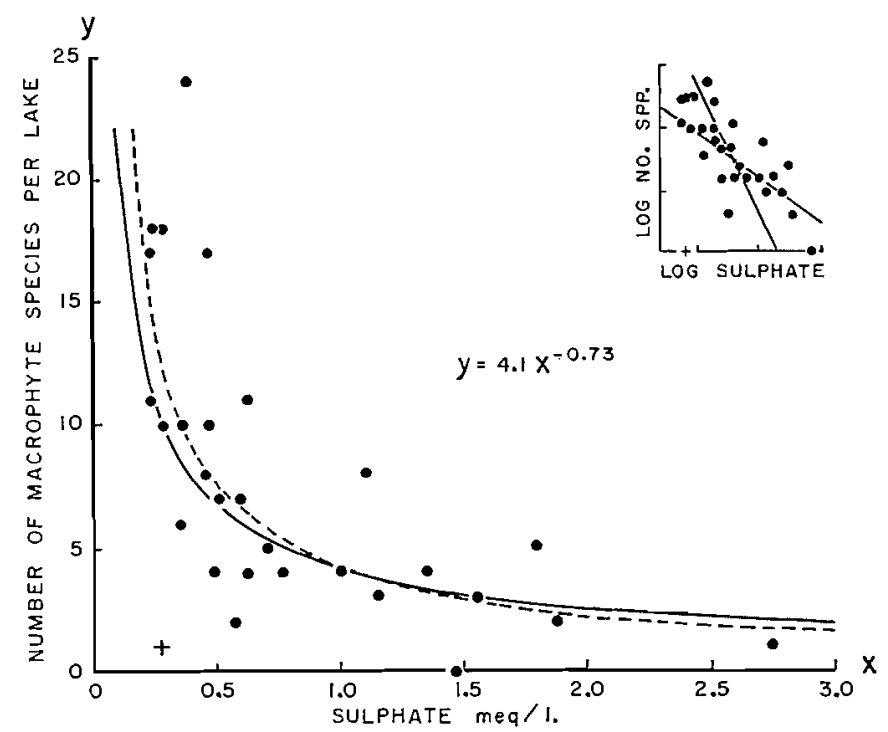

FIG. 2. The relation between the number of species in a pond or lake and its sulphate concentration (the solid line includes all lakes, while the broken line excludes lake No. 105, represented by point $t$ ). 
The relationship between floristic abundance and pollution is well shown by plotting species number $(y)$ versus sulphate concentration $(x)$, as in Fig. 2. In this case the regression equation is $y=4.13 x^{-0.728}$, as indicated by the solid line in Fig. 2, with the standard error of estimate 2.0 species, and the correlation coefficient $r=-0.60$. If lake No. 105, with its unusually low species number (see "+" in Fig. 2), is omitted, the correlation coefficient $r=-0.79$, and the regression equation becomes $y=4.15 x^{-0.90 \bar{a}}$, as shown by the broken line in Fig. 2, with the standard error of estimate 1.6 species.

The divergence of lake No. 105 from the general group is evident from the $\log / \log$ plot inset in Fig. 2, but this lake is in no way unusual in its level of sulphate, calcium, or acidity (see Table I). It differs physically fron the others in having a botton composed largely of boulders, but a few sand patches were observed which might have been expected to support a rather greater variety of flora. Unfortunately its inaccessibility prevents further investigation.

Whether lake No. 105 is included in the regression makes little difference to the relationship illustrated in Fig. 2, from which it is clear that sites subject to heavy sulphur pollution exhibit a marlked degree of floristic impoverishment. This seems unlikely to be caused by abundance of sulphate ion, which has been analyzed merely as a good pollution index, and may be due in part to the high levels of acidity in many such waters (e.g. Nos. 8, 11, 12, 14, all below pH 4). Strong acidity is not accompanied by low calcium levels, as is so of ten the case in acid bog lakes (Gorhan 1957), but rather by higher concentrations, owing to increased weathering of calcium from the soils by sulphuric acid. Moreover, three waters with high sulphate levels are not very acid (Nos. $56,65,69$, all above $\mathrm{pH} 6$ ), and yet are floristically poor, the number of species ranging from two to five per lake. Since it is difficult to imagine that sulphate itself is toxic at the levels observed $(0.8$ to $1.9 \mathrm{meq} / 1$.$) , the cause of floristic$ poverty must be sought elsewhere. In the course of chemical analysis it was found that heavy metals were abundant in waters collected near the smelters, and had to be complexed by cyanide before satisfactory calcium titrations could be carried out. These heavy metals might be presumed to consist mainly of the copper and nickel smelted at Sudbury, but others (e.g. iron, manganese) might also be leached from rocks and soils under the influence of sulphuric acid produced by oxidation of sulphur dioxide from the smelter chimneys. In addition, preliminary investigations have revealed a strong positive correlation between copper and sulphate in melted snow collected at varying distances NNW. from the Falconbridge smelter, with high concentrations of botl near the chimneys, as shown in Table IV. It therefore seems likely that heavy metals such as copper, and perhaps other elements (nickel has not so far been investigated), may reach toxic levels in waters subject to severe aerial pollution, and so account for species impoverishment even where the waters are not strongly acid. Indeed, it is quite conceivable that high acidity is of minor importance, and that heavy metal toxicity is the major factor limiting floristic variety in waters receiving much fallout from the Sudbury smelters. In this connection studies of the relative tolerance of species such as Eleocharis acicularis and Potamogeton epihydrus v. nuttallii for high levels of both acidity and copper might prove informative. 
TABLE IV

Chemical analyses of snow samples collected on the ground near Falconbridge, February 12-15, 1960

\begin{tabular}{|c|c|c|c|c|}
\hline $\begin{array}{c}\text { Distance NNW. } \\
\text { of smelter, } \\
\text { mi }\end{array}$ & $\mathrm{pH}$ & $\begin{array}{l}\mathrm{SO}_{4} \\
\text { meq } / 1\end{array}$ & $\begin{array}{c}\mathrm{Ca}, \\
\mathrm{meq} / 1 .\end{array}$ & $\begin{array}{l}\mathrm{Cu}^{*} \\
\text { acid-sol. } \\
\mu \mathrm{g} / 1 .\end{array}$ \\
\hline 0.8 & 3.8 & 0.39 & 0.045 & 2300 \\
\hline 1.0 & 4.3 & 0.09 & 0.015 & 300 \\
\hline 1.4 & 3.7 & 0.47 & 0.040 & 2000 \\
\hline 2.5 & 4.5 & 0.12 & - & 650 \\
\hline 3.2 & 4.3 & 0.10 & 0.018 & 100 \\
\hline 3.3 & 4.6 & 0.03 & 0.010 & Ca. 5 \\
\hline 5.3 & 4.4 & 0.05 & 0.015 & $<5$ \\
\hline 7.4 & 4.5 & 0.03 & 0.013 & $<5$ \\
\hline
\end{tabular}

*Biquinoline method in Beckman DU spectrophotometer.

\section{Acknowledgments}

It is a pleasure to express once again our gratitude to Mr. Keith Acheson, Regional Director of the Ontario Department of Lands and Forests, for arranging helicopter flights, and to Mr. R. F. Ross for taking us wherever we wished to go. Drs. J. H. Soper and R. F. Cain of the Botany Department, University of Toronto, very kindly identified or checked most of the higher plants and bryophytes respectively.

Supporting funds were kindly granted by the Advisory Committee on Scientific Research, University of Toronto, and the National Research Council of Canada.

\section{References}

Gorfam, E. 1957. The chenical composition of lake waters in Halifax County, Nova Scotia. Limnology \& Oceanog. 2, 12-21.

Gorham, E. and Gordon, A. G. 1960a. Some effects of smelter pollution northeast of Falconbridge, Ontario. Can. J. Botany, 38, 307-312.

$1960 \mathrm{~b}$. The influence of smelter fumes upon the chemical composition of lake waters near Sudbury, Ontario, and upon the surrounding vegetation. Can. J. Botany, 38, $477-487$.

Yoshimura, S. 1935. Lake Akanuma, a siderotrophic lake, at the foot of volcano Bandai, Hukusina Prefecture, Japan. Proc. Imp. Acad. Tokyo, 11, 426-428. 